\title{
ANALISIS REAKSI PASAR MODAL TERHADAP PENGANGKATAN JOKO WIDODO SEBAGAI PRESIDEN REPUBLIK INDONESIA
}

\author{
Ida Nuryana \\ Program Studi Manajemen, Fakultas Ekonomika dan Bisnis Universitas Kanjuruhan \\ email :mediaidafeb@unikama.ac.id
}

\begin{abstract}
This study aims to measure the presence or absence of the information content of Joko Widodo appointment as the President of Republic Indonesia in terms of the significance of abnormal return and trading volume activity, and to know the difference in the average abnormal return and trading volume activity before and after the inauguration events. Observation period used is 11 days, with details 5 days before, 5 days after and 1 day at the day of inauguration, which is dated October 20th, 2014. This study uses secondary data obtained from the website of Indonesia Stock Exchange. The data used in this study are the closing price (close price) stocks that were sampled, stock index KOMPAS100, daily trading volume (tradeable share), and the number of outstanding shares of the issuer sampled. The sample used in this study are manufacturing stocks that were listed in the index KOMPAS100. The sampling technique is done by using purposive sampling, that decision based on certain criteria. To determine whether there is significance of these two variables, this research conducts event study analysis method, while to know the difference in the average abnormal return and the average trading volume activity, it applies non-parametric test which is Wilcoxon signed rank test. The results show that the appointmrnt occurrence of Joko Widodo as a President doesn't contain any information. It is evidenced by the unsignificant value of abnormal return and trading volume activity during the observation period. The market also did not react to that information proved by the results of different test average of the two variables before and after the events that have a probability value ( $p$-value) above the $5 \%$ error level.
\end{abstract}

Keywords : event study, information content, President Joko Widodo, abnormal return, trading volume activity

\begin{abstract}
ABSTRAK
Penelitian ini bertujuan untuk mengukur ada tidaknya kandungan informasi dari peristiwa pengangkatan Joko Widodo sebagai Presiden Republik Indonesia dilihat dari signifikansi abnormal return dan trading volume activity, serta mengetahui perbedaan rata-rata abnormal return dan trading volume activity sebelum dan sesudah peristiwa pelantikan. Periode pengamatan yang digunakan adalah 11 hari, dengan rincian 5 hari sebelum, 5 hari sesudah dan 1 hari saat pelantikan terjadi, yaitu tanggal 20 Oktober 2014. Penelitian ini menggunakan data sekunder yang diperoleh dari website Bursa Efek Indonesia. Data yang digunakan dalam penelitian ini meliputi harga penutupan (close price) saham yang dijadikan sampel, indeks saham Kompas100, volume perdagangan harian (tradeable share), dan jumlah saham beredar dari emiten yang dijadikan sampel. Sampel yang digunakan dalam penelitian ini adalah saham-saham manufaktur yang ter-list dalam indeks Kompas100. Teknik pengambilan sampel dilakukan dengan teknik purposive sampling, yaitu pengambilan berdasarkan kriteria-kriteria tertentu. Untuk mengetahui ada tidaknya signifikansi dari kedua variabel dilakukan dengan metode analisis event study, sedangkan untuk mengetahui perbedaan rata-rata abnormal return dan rata-rata trading volume activity menggunakan uji non-parametrik yaitu wilcoxon signed rank test. Hasil penelitian menunjukkan bahwa peristiwa pengangkatan Joko Widodo sebagai Presiden tidak memilik kandungan informasi. Hal ini dibuktikan dengan tidak signifikannya nilai abnormal return dan trading volume activity selama periode pengamatan. Pasar juga tidak bereaksi atas informasi tersebut dibuktikan dari hasil uji beda rata-rata kedua variabel sebelum dan sesudah peristiwa yang mempunyai nilai probabilitas (p-value) diatas taraf kesalahan 5\%.
\end{abstract}

Kata kunci : event study, kandungan informasi, Presiden Joko Widodo, abnormal return, trading volume activity. 


\section{PENDAHULUAN}

Sebagai suatu instrumen ekonomi, pasar modal tidak lepas dari berbagai pengaruh lingkungan, baik lingkungan ekonomi maupun lingkungan non ekonomi. Pengaruh lingkungan ekonomi mikro seperti kinerja perusahaan, perubahan strategi perusahaan, pengumuman laporan keuangan atau dividen perusahaan selalu mendapat tanggapan dari pelaku pasar di pasar modal. Selain itu, perubahan lingkungan ekonomi makro yang terjadi seperti perubahan suku bunga tabungan dan deposito, kurs valuta asing, inflasi, serta berbagai regulasi dan deregulasi ekonomi yang dikeluarkan pemerintah, turut berpengaruh pada fluktuasi harga dan volume perdagangan di pasar modal. (Pronayuda, 2006)

Perubahan faktor-faktor makro tersebut tidak dengan seketika mempengaruhi kinerja perusahaan, tetapi secara perlahan dalam jangka panjang. Sebaliknya, harga saham akan terpengaruh dengan seketika oleh perubahan faktor makro tadi karena investor lebih cepat bereaksi. Ketika perubahan faktor makro ekonomi itu terjadi, investor akan mengkalkulasi dampaknya baik yang positif maupun negatif terhadap kinerja perusahaan beberapa waktu ke depan, kemudian mengambil keputusan membeli atau menjual saham yang yang bersangkutan.

Pengaruh lingkungan makro dan non ekonomi, walaupun tidak terkait secara langsung dengan dinamika yang terjadi dipasar modal tidak dapat dipisahkan dari aktivitas bursa saham. Lingkungan non ekonomi tersebut seperti berbagai isu mengenai kepedulian terhadap lingkungan hidup, hak asasi manusia, serta peristiwa-peristiwa politik kerap kali menjadi faktor utama pemicu fluktuasi harga saham di bursa efek seluruh dunia. Suryawijaya dan Setiawan dalam Zaqi (2006) menyatakan, makin pentingnya peran bursa saham dalam kegiatan ekonomi, membuat bursa semakin sensitif terhadap berbagai peristiwa disekitarnya, baik berkaitan atau tidak berkaitan secara langsung dengan isu ekonomi. Peristiwa-peristiwa politik, seperti adanya pergantian pemerintahan, pengumuman kabinet menteri, kerusuhan politik, peperangan dan peristiwa lainnya sangat mempengaruhi harga dan volume perdagangan di bursa efek karena peristiwa-peristiwa politik berkaitan erat dengan kestabilan perekonomian negara.

Selain itu peristiwa politik juga menyebabkan tingkat kepercayaan yang negatif dari para investor, sehingga adanya peristiwa politik yang mengancam stabilitas negara cenderung mendapat respon negatif dari pelaku pasar. Krisis ekonomi yang melanda Indonesia sejak Juli 1997 tidak hanya berdampak pada kondisi perekonomian tetapi juga telah merubah peta politik di Indonesia. Akibatnya, pemulihan sektor ekonomi di Indonesia tidak hanya tergantung pada kebijakan-kebijakan ekonomi yang dilakukan pemerintah tetapi juga pada kestabilan politik yang sejak terjadinya krisis ekonomi tidak lagi pernah dirasakan bahkan terkesan terjadi perebutan kekuasaan di tingkat elit politik Indonesia. Situasi ini berdampak pada perkembangan pasar modal Indonesia yang tercermin dari harga saham dan volume perdagangan saham di Bursa Efek.

Gejolak kehidupan politik, secara langsung maupun tidak langsung, juga memiliki pengaruh terhadap kondisi ekonomi di sebuah negara. Perubahan di dalam lembaga legislatif maupun di dalam lembaga eksekutif, sebagai bagian dari peristiwa politik, dapat mempengaruhi kondisi ekonomi negara (Alkaff, 2010). Hal ini dikarenakan kondisi ekonomi suatu negara akan dipengaruhi oleh kebijakan-kebijakan yang ditentukan baik oleh lembaga legislatif maupun lembaga eksekutif. Perubahan dalam kedua lembaga tersebut terjadi melalui Pemilihan Umum (Pemilu), Pemilihan Presiden baru, serta penyusunan kabinet baru.

Kegiatan perdagangan efek - terutama kegiatan di bursa saham, sebagai bagian dari aktivitas ekonomi- tak luput dari pengaruh gejolak politik tersebut. Peristiwa politik memang tidak mengintervensi bursa saham secara langsung, namun peristiwa ini merupakan salah satu informasi yang diserap oleh para pelaku pasar modal dan digunakan oleh para pelaku ini untuk memperoleh keuntungan yang diharapkan di masa yang akan datang. Informasi tersebut mempengaruhi pengambilan keputusan para investor dan pada akhirnya pasar bereaksi 
terhadap informasi tersebut untuk mencapai keseimbangan baru, sehingga dapat dikatakan bahwa peristiwa politik secara tidak langsung mempengaruhi aktivitas di bursa efek.

Salah satu peristiwa politik yang hendak diuji kandungan informasinya terhadap aktivitas bursa efek adalah peristiwa pengangkatan Presiden Indonesia ketujuh, JW/Joko Widodo pada tanggal 20 Oktober 2014. Pengujian kandungan informasi peristiwa pengangkatan Presiden Joko Widodo terhadap aktivitas bursa efek ini dimaksudkan untuk melihat reaksi pasar terhadap pengumuman pengangkatan Presiden Indonesia ketujuh tersebut yang dapat diukur dengan menggunakan abnormal return. Jogiyanto (2003) menyatakan bahwa event study merupakan studi yang mempelajari reaksi pasar terhadap peristiwa (event) yang informasinya dipublikasikan sebagai suatu pengumuman. Event study dapat digunakan untuk menguji kandungan informasi (information content) dari suatu pengumuman. Pengujian kandungan informasi dimaksudkan untuk melihat reaksi dari suatu pengumuman.

Jika pelantikan tersebut mengandung informasi, maka diharapkan pasar akan bereaksi pada waktu pengumuman tersebut diterima oleh pasar. Reaksi pasar ditunjukkan dengan adanya perubahan harga dari sekuritas bersangkutan. Reaksi ini dapat diukur dengan menggunakan return sebagai nilai perubahan harga atau dengan menggunakan abnormal return. Jika digunakan abnormal return maka dapat dikatakan bahwa suatu pengumuman yang mempunyai kandungan informasi akan memberikan abnormal return kepada pasar. Sebaliknya yang tidak mengandung informasi tidak akan memberikan abnormal return kepada pasar. Selain menggunakan abnormal return, reaksi pasar modal terhadap informasi juga dapat dilihat melalui parameter pergerakan aktivitas perdagangan di pasar (Trading volume activity), dimana bila investor menilai suatu peristiwa mengandung informasi maka peristiwa tersebut akan mengakibatkan keputusan perdagangan diatas keputusan perdagangan yang normal.

\section{TINJAUAN PUSTAKA}

\section{Pasar Modal}

Menurut Sunariyah (2000), pasar modal secara umum adalah suatu sistem keuangan yang terorganisasi, termasuk di dalamnya adalah bankbank komersial dan semua lembaga perantara dibidang keuangan, serta keseluruhan surat-surat berharga yang beredar. Pasar modal dalam arti sempit, adalah suatu pasar (tempat,berupa gedung) yang disiapkan guna memperdagangkan saham-saham, obligasi-obligasi, dan jenis surat berharga lainnya dengan memakai jasa perantara pedagang efek. Menurut Marzuki dalam Hermuningsih (2012), pasar modal adalah pelengkap di sektor keuangan terhadapa dua lembaga lainnya, yaitu bank dan lembaga pembiayaan. Pasar modal memberikan jasanya yaitu menjembatani hubungan antar pemilik modal yang disebut pemodal (investor) dengan peminjam dana yang disebut emiten (perusahaan yang go public). Investor membeli instrumen pasar modal untuk keperluan investasi portofolio sehingga akan memaksimumkan penghasilan.

\section{Saham}

Menurut Susilo dalam Hermuningsih (2012), saham adalah tanda penyertaan modal seseorang atau pihak (badan usaha) dalam suatu perusahaan atau perseroan terbatas. Suatu perusahaan dapat menjual hak kepemilikannya dalam bentuk saham (stock). Jika perusahaan hanya mengeluarkan satu kelas saham saja, saham ini disebut dengan saham biasa (common stock). Untuk menarik investor potensial lainnya, suatu perusahaan mungklin juga menegeluarkan kelas lain dari saham, yaitu yang disebut dengan saham preferen (preferred stock). Saham preferen mempunyai hak-hak prioritas lebih dari saham biasa. Hak-hak prioritas dari saham preferen yaitu hak atas dividen yang tetap dan hak terhadap aktiva jika terjadi likuidasi. (Jogiyanto, 2003)

\section{Efisiensi Pasar}

Menurut Beaver dalam Jogiyanto (2003), efisiensi pasar didefinisikan sebagai hubungan antara harga-harga sekuritas dengan informasi. Bagaimana suatu pasar bereaksi terhadap suatu informasi untuk mencapai harga keseimbangan yang baru merupakan hal yang penting. Jika 
pasar bereaksi dengan cepat dan akurat untuk mencapai harga keseimbangan baru yang sepenuhnya mencerminkan informasi yang tersedia, maka kondisi pasar seperti ini disebut dengan pasar efisien. Dengan demikian ada hubungan antara teori pasar modal yang menjelaskan tentang keadaan ekuilibrium dengan konsep pasar efisien yang mencoba menjelaskan bagaimana pasar memproses informasi untuk menuju pasar ekuilibrium yang baru. Efisiensi pasar seperti ini disebut dengan efisiensi pasar secara informasi (informationally efficient market) yaitu bagaimana pasar bereaksi terhadap informasi yang tersedia. (Jogiyanto,2003)

Menurut Sunariyah dalam Indarawati (2010), pasar modal dikatakan efisien bila harga saham mampu menggambarkan kondisi perekonomian secara umum atau keadaan perusahaan. Efisien pasar modal ditentukan oleh seberapa besar pengaruh informasi yang relevan, yang dipertimbangkan dalam pengambilan keputusan investasi. Adanya berbagai situasi maupun kondisi yang berbeda di antar negara satu dengan yang lainnya menyebabkan efisiensi pasar pada suatu negara akan berbeda dengan negara yang lain.

\section{Indeks Kompas 100}

Pada perayaan HUT PT. Bursa Efek Indonesia ke-15 pada tanggal 13 Juli 2007, BEI meluncurkan indeks Kompas100. Indeks ini diharapkan dapat memberi manfaaatbagi investor, pengelola portofolio, serta fund manager sehingga dapat digunakan sebagai acuan dalam menciptakan kreativitas (inovasi) pengelolaan dana yang berbasis saham. Proses pemilihan 100 saham yang masuk dalam penghitungan indeks Kompas100 ini mempertimbangkan faktor likuiditas, kapitalisasi pasar dan kinerja fundamental dari saham-saham tersebut.

\section{Event Study}

Studi peristiwa atau bisa juga disebut Event study diartikan sebagai mempelajari suatu peristiwa terhadap harga saham di pasar, baik pada saat peristiwa itu terjadi maupun beberapa saat setelah peristiwa itu terjadi. Apakah harga saham akan meningkat atau menurun setelah peristiwa itu terjadi atau apakah harga saham sudah terpengaruh sebelum peristiwa itu terjadi secara resmi. Sedang pengertian event study yang berhubungan dengan return saham menurut Kritzman dalam Zaqi (2006), event study bertujuan untuk mengukur hubungan antara suatu peristiwa dengan tingkat pengembalian (return) dari suatu surat berharga, selian itu event study juga dapat digunakan untuk mengukur dampak suatu peristiwa ekonomi terhadap nilai perusahaan.

Dasgupta dkk. dalam Indrawati (2010) mendefinisikan event study sebagai penelitian secara empiris terhadap harga dan aset sebelum dan sesudah peristiwa tertentu seperti pengumuman merger atau pembagian deviden. Event study dapat digunakan untuk mengetahui reaksi investor terhadap berita baik dan berita buruk. Metodologi ini berdasarkan pada asumsi bahwa pasar modal secara efisisen dapat mengevaluasi dampak dari informasi baru dalam memprediksikan keuntungan perusahaan di masa datang.

\section{Abnormal Return dan Expected Return}

Efisiensi pasar diuji dengan melihat retrurn tidak normal (abnormal return) yang terjadi. Pasar dikatakan tidak efisien jika satu atau beberapa pelaku pasar dapat menikmati return yang tidak normal dalam jangka waktu yang cukup lama. Studi peristiwa menganalisis return tidak normal (abnormal return) dari sekuritas yang mungkin terjadi di sekitar pengumuman dari suatu peristiwa. Abnormal return atau excessreturn merupakan kelebihan dari return yang sesungguhnya terjadi terhadap return normal. Return normal merupaka return ekspetasi (return yang diharapkan).

Abnormal return dirumuskan sebagai berikut: Dimana:

$$
\mathrm{AR}_{\mathrm{it}}=\mathrm{R}_{\mathrm{it}}-\mathrm{E}\left(\mathrm{R}_{\mathrm{it}}\right)
$$

$\mathrm{AR}_{\text {it }}=$ abnormal return untuk saham i pada waktu $\mathrm{t}$

$\mathrm{R}_{\mathrm{it}} \quad=$ return sesungguhnya yang terjadi untuk saham i pada waktu t

$\mathrm{E}\left(\mathrm{R}_{\mathrm{it}}\right)=$ return ekspektasi yang terjadi untuk saham i pada waktu $t$ 
Sedangkan expected return merupakan return yang harus diestimasi. Return ekspektasi dapat dirumuskan dalam bentuk berikut:

$$
\begin{aligned}
& \text { Dimana: } \mathrm{E}\left(\mathrm{R}_{\mathrm{it}}\right)=\mathrm{Rm}_{\mathrm{t}} \\
& \mathrm{E}(\mathrm{Rit})=\begin{array}{l}
\text { return ekspektasi yang terjadi untuk } \\
\text { saham i pada waktu } \mathrm{t}
\end{array} \\
& \mathrm{Rmt}=\text { return index pasar pada waktu } \mathrm{t}
\end{aligned}
$$

\section{Trading Volume Activity (TVA)}

Menurut Hakim dalam Indrawati (2010), TVA adalah suatu instrumen yang dapat digunakan untuk melihat reaksi pasar modal terhadap informasi melalui parameter pergerakan aktivitas volume perdagangan saham di pasar modal. Dengan menggunakan TVA, maka dpat dikaji apakah peristiwa pelantikan Joko Widodo sebagai Presiden Republik Indonesia dapat membuat keputusan perdagangan di atas keputusan perdagangan yang normal. Hal tersebut dapat diketahui dengan perhitungan agregat TVA masing-masing sekuritas dengan cara membandingkan jumlah saham perusahaan yang diperdagangkan dalam sutu periode teretentu dengan keseluruhan jumlah saham yang beredar pada saat periode peristiwa.

Volume perdagangan yang kecil menunjukkan investor yang sedikit atau kurang tertarik dalam melakukan investasi di pasar modal, sedangkan volume perdagangan yang besar menunjukkan banyaknya investor dan banyaknya minat untuk transaksi jual beli saham. Volume perdagangan kecil merupakan suatu tanda ketidakpastian atau ketidakyakinan investor di masa yang akan datang. Kenaikan volume akan semakin tinggi dengan meningkatnya ketidaksepakatan para investor tentang interpretasi mereka atas suatu pengumuman yang dipublikasikan. (Cahyono, 2014).

$T V A=\frac{\text { ESaham perusahaan } i \text { yang diperdagang } k a n \text { pada waktu } t}{\text { ESaham perusahaan } \text { yang beredar pada waktu } t}$

\section{Macam Peristiwa}

Studi peristiwa (event study) melibatkan suatu peristiwa yang terjadi. Dalam hal ini memahami macam-macam peristiwa perlu dilakukan karena dampak dari suatu peristiwa dapat berbeda-beda. Beberapa persitiwa dapat berdampak pada suatu perusahaan saja, pada suatu indiustri tertentu atau bahkan pada seluruh pasar modal. (Nur Islami, 2011). Grar dalam Jogiyanto dalam Nur Islami (2011) mendefinisikan suatu peristiwa sebagai informasi publik di pasar yang mempengaruhi nilai satu atatu lebih perusahaan pada saat yang sama. Suatu peristiwa dapat dikelompokkan ke dalam beberapa kategori menurut tipe, dampak dan waktu peristiwanya.

a. Peristiwa Berdasarkan Tipe

b. Peristiwa Berdasarkan Sumbernya

c. Peristiwa Berdasarkan Dampak

d. Peristiwa Berdasarkan Waktu

\section{Tinjauan Empiris}

1. Penelitian terdahulu tentang event study yang dilakukan oleh Swastika (2012) menguji kandungan informasi dari peristiwa pemilihan gubernur DKI Jakarta Putaran II tahun 2012, menggunakan indikator abnormal return dan trading volume activity. Penelitian ini berkesimpulan, pasar modal merespon informasi dari peristiwa Pilkada DKI Jakarta Putaran II sebagai good news, ditunjukkan oleh muculnya rata-rata abnormal return yang bernilai positif signifikan di sekitar tanggal terjadinya peristiwa.

2. Penelitian selanjutnya dilakukan oleh Siregar dan Selvia (2004) yang meneliti tentang reaksi pasar modal terhadap hasil pemilihan umum dan pergantian pemerintahan tahun 2004. Hasil penelitian menunjukkan pasar modal bereaksi posiitif terhadap peristiwa pengumuman hasil pemilu yang menyatakan bahwa Susilo Bambang Yudhoyono sebagai Presiden terpilih. Selain karena peristiwa ini merupakan peristiwa langka yang menunjukkan perkembangan demokrasi di Indonesia karena pertama kalinya pemilihan presiden secara langsung dilakukan.

3. Sedangkan Pronayuda (2009) dalam penelitiaannya menguji kandungan informasi dari peristiwa pengumuman Kabinet Indonesia Bersatu. Hasil penelitian 
mengatakan bahwa pasar modal Indonesia bereaksi terhadap peristiwa pengumuman Kabinet Indonesia Bersatu yang terlihat dari adanya perbedaan rata-rata aktivitas volume perdagangan (Trading volume activity) sebelum dan sesudah pengumuman bagi perusahaan yang memiliki market kapitalisasi besar. Namun tidak halnya bagi perusahaan yang memiliki market kapitalisasi kecil.

4. Peristiwa politik lainnya adalah peristiwa kemunduran Sri Mulyani dari jabatan Menteri Keuangan pada tanggal 5 Mei 2010. Aseptin (2010) sebagai peneliti menyatakan pengunduran diri Sri Mulyani berdampak negatif terhadap perdagangan saham di Bursa Efek Indonesia. Secara umum, pelaku pasar prihatin dengan kemudurannya karena kinerja Sri Mulyani dinilai baik sebelum terjadinya peristiwa tersebut. Dari analisis data yang dilakukan menunjukkan, ada perbedaan signifikan abnormal return sebelum dan sesudah peristiwa mundurnya Sri Mulyani sebagi Menteri Keuangan. Namun dalam pengujian tentang Trading volume activity sebelum dan sesudah peristiwa tidak terbukti adanya perbedaan yang signifikan.

5. Penelitian selanjutnya tentang event study dilakukan oleh Alkaff (2009) yang meneliti kandungan informasi dari peristiwa pemilihan Presiden Republik Indonesia pada tahun 2009. Peneliti menggunakan indikator abnormal return dan trading volume activity. Berdasarkan hasil analisis disimpulkan bahwa dari 15 periode pengamatan terdapat signifikansi reaksi pasar atau abnormal return saham pada 4 periode sebelum $(\mathrm{t}-4$, $\mathrm{t}$ $3, \mathrm{t}-2, \mathrm{t}-1)$ dan 2 periode setelah $(\mathrm{t}+6, \mathrm{t}+7)$ pemilihan Presiden RI tanggal 8 Juli 2009. Disimpulkan pula bahwa tidak terdapat perbedaan yang signifikan dalam abnormal return dan volume perdagangan antara periode 7 hari sebelum dan 7 hari sesudah terjadinya peristiwa.

6. Penelitian lainnya yang terkait dengan event study adalah yang dilakukan Nur Islami (2011). Penelitian tersebut menguji kandungan informasi dari peristiwa kemunduran Sri Mulyani dari jabatan Menteri Keuangan. Indikator yang dipakai peneliti adalah Abnormal Return, Trading Volume Activity dan Security Return Variability. Sampel yang dipakai peneliti adalah dari indeks LQ45 dengan menggunakan teknik Purposive Sampling. Hasil penelitian menunjukkan AR dan TVA signifikan pada saat pengumuman peristiwa sedangkan indikator SRV tidak signifikan

\section{Kerangka Konsep dan Hipotesis}

Gambar 1 Kerangka Konsep Penelitian

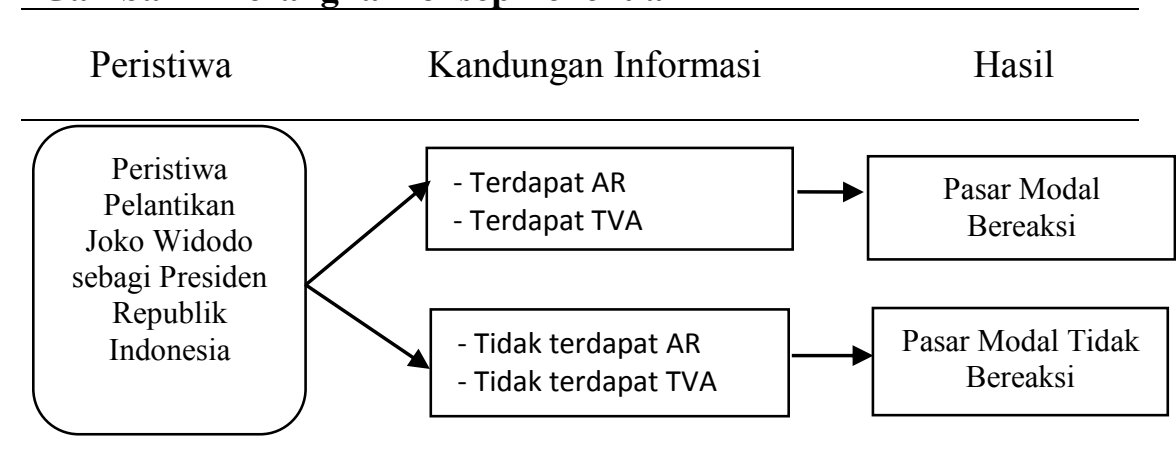

H1 : Pasar modal bereaksi terhadap peristiwa pelantikan Joko Widodo sebagai presiden dilihat dari abnormal return.
H2 : Pasar modal bereaksi terhadap peristiwa pelantikan Joko Widodo sebagai presiden dilihat dari trading volume activity. 


\section{METODE PENELITIAN}

Periode pengamatan yang digunakan adalah 11 hari, dengan rincian 5 hari sebelum, 5 hari sesudah dan 1 hari saat pengangkatanterjadi, yaitu tanggal 20 Oktober 2014. Penelitian ini menggunakan data sekunder yang diperoleh dari website Bursa Efek Indonesia. Data yang digunakan dalam penelitian ini meliputi harga penutupan (close price) saham yang dijadikan sampel, indeks saham Kompas100, volume perdagangan harian (tradeable share), dan jumlah saham beredar dari emiten yang dijadikan sampel. Sampel yang digunakan dalam penelitian ini adalah saham-saham manufaktur yang ter-list dalam indeks Kompas100. Teknik pengambilan sampel dilakukan dengan teknik purposive sampling, yaitu pengambilan berdasarkan kriteria-kriteria tertentu. Untuk mengetahui ada tidaknya signifikansi dari kedua variabel dilakukan dengan metode analisis event study, sedangkan untuk mengetahui perbedaan rata-rata abnormal return dan rata-rata trading volume activity menggunakan uji non-parametrik yaitu wilcoxon signed rank test.

\section{PEMBAHASAN}

\section{Pembahasan Hipotesis 1}

Berdasarkan hasil analisis tentang abnormal return yang telah dijelaskan pada bab sebelumnya dapat dinyatakan bahwa peristiwa pengangkatan Joko Widodo sebagai Presiden Republik Indonesia tidak memiliki kandungan informasi sehingga pasar tidak terpengaruh. Hal ini dibuktikan oleh adanya 10 nilai abnormal return yang tidak signifikan selama 11 hari periode pengamatan. Nilai average abnormal return juga menunjukkan tidak adanya perbedaan yang signifikan antara abnormal return sebelum dan sesudah peristiwa pelantikan Joko Widodo sebagai Presiden. Hal ini ditunjukkan dengan nilai probabilitas ( $p$-value) sebesar 0,893 yang berarti diatas taraf kesalahan $5 \%(0,05)$.

Hasil penelitian ini hampir sama dengan penelitian yang dilakukan oleh Siregar dan
Selvia (2004) tentang reaksi pasar modal terhadap hasil pemilu tahun 2004. Hasil penelitian tersebut mengungkapkan tidak adanya perbedaan abnormal return sebelum dan sesudah pengumuman hasil pemilu. Peneliti menjelaskan penyebab tidak adanya perbedaan tersebut karena sikap pelaku pasar modal yang masih bersifat wait and see terhadap janji-janji Susilo Bambang Yudhoyono yang diungkapkan pada saat kampanye. Kesamaan lainnya adalah ditolaknya hipotesis yang menyatakan "ada perbedaan abnormal return sebelum dan sesudah pengakatan Presiden".

Suatu peristiwa yang bisa menyebabkan pasar bereaksi adalah peristiwa yang bersifat kejutan, karena suatu peristiwa yang mendadak tidak akan memberikan kesempatan bagi pelaku pasar untuk melakukan tindakan antisipasi terhadap peristiwa tersebut. Isu bahwa pasar merespon positif Joko Widodo menjadi Presiden RI sudah dicerna investor sejak penetapan hasil pemilu saat quick count dan pengumuman resmi oleh KPU. Sehingga peristiwa pengangkatan Joko Widodo oleh Mahkamah Agung (MA) pada 20 Oktober 2014 oleh investor dianggap sudah tidak mempunyai kandungan informasi lagi.

Perihal adanya respon positif yang tercantum pada latar belakang penelitian ini, itu memang terjadi yakni perubahan nilai Average Abnormal return (AAR) sebesar $-0,0076$ pada periode $\mathrm{t}_{0}$ menjadi $-0,0007$ pada periode $t_{+1}$. Walaupun bukan nilai yang signifikan, hal ini membuktikan adanya euforia sesaat oleh investor atas pengangkatan Joko Widodo sebagai Presiden Republik Indonesia. Euforia ini dikarenakan adanya kepastian masyarakat akan Presiden baru mereka. Walaupun sejak jauh hari mereka mengetahui bahwa Joko Widodo adalah Presiden terpilih, namun belum sah bila belum dilantik oleh Mahkamah Agung. Kejadian ini juga berarti bahwa negara secara resmi mengakui pemimpin barunya.

\section{Pembahasan Hipotesis 2}

Reaksi pasar modal terhadap informasi juga dapat dilihat melalui parameter pergerakan 
aktivitas perdagangan dipasar (trading volume activity), dimana bila investor menilai suatu peristiwa mengandung informasi maka peristiwa tersebut akan mengakibatkan keputusan perdagangan di atas keputusan perdagangan yang normal. (Agustina, 2013 dalam Alkaff, 2012). Hasil analisis statistik pada bab sebelumnya menerangkan bahwa tidak ada signifikansi nilai trading volume activity (TVA) selama 11 hari periode pengamatan. Begitu juga hasil uji wilcoxon signed rank test yang mana adalah untuk menguji perbedaan rata-rata TVA sebelum dan sesudah pelantikan menunjukkan tidak ada perbedaan rata-rata TVA. Hasil tersebut ditunjukkan dengan nilai probabilitas ( $p$-value) sebesar 0,686 . Nilai tersebut adalah lebih besar dari taraf kesalahan $5 \%(0,05)$.

Tidak adanya nilai trading volume activity yang signifikan selama periode peristiwa menunjukkan bahwa pengangkatan Joko Widodo sebagai Presiden Republik Indonesia bukan momentum yang menyebabkan para investor melakukan perdagangan yang ekstrim. Hasil penelitian ini memiliki kesamaan dengan penelitian yang dilakukan oleh Agustina (2013) dimana tidak terdapat nilai signifikansi pada TVA saat peristiwa redenominasi rupiah.

Dengan tidak signifikannya nilai abnormal return juga turut mempengaruhi aktivitas investor dalam jual beli saham. Aktivitas tersebut cenderung rendah karena tidak ada abnormal return yang diperoleh investor, sehingga investor akan lebih memilih menahan sahamnya. Sebaliknya apabila ada abnormal return maka secara tidak langsung juga mempengaruhi trafik volume perdagangan pasar modal. Karena ada abnormal return maka investor tergerak melakukan jual beli sahamnya.

Terkait naiknya return dan trading volume activity pada $\mathrm{t}_{-1}$ kemungkinan pasar merespon positif perihal pertemuan Presiden terpilih Joko Widodo dan lawan politiknya sekaligus musuh saat pemilu presiden, Prabowo Subianto (news.okezone.com, 16 Oktober 2014).

Dengan adanya pertemuan ini investor berharap terciptanya iklim politik yang sehat di masa mendatang. Karena seperti diketahui iklim politik Indonesia sempat memanas tatkala hasil Pemilu presiden tersebut. Dikatakan demikian karena kedua kubu saling mengklaim kemenangannya. Namun hasil putusan final KPU lah yang menyatakan Joko Widodo sebagai presiden terpilih.

\section{KESIMPULAN}

1. Peristiwa pengangkatan Joko Widodo sebagai Presiden Republik Indonesia tidak memberikan abnormal return yang signifikian kepada investor. Hal ini dibuktikan dengan adanya 10 hari pengamatan yang memiliki nilai abnormal return tidak signifikan. Dengan kata lain, pelantikan Joko Widodo tidak memiliki kandungan informasi yang menyebabkan pasar modal bereaksi dilihat dari abnormal return.

2. Peristiwa pengangkatan Joko Widodo sebagai Presiden tidak menyebabkan adanya nilai trading volume activity yang signifikan selama periode peristiwa. Sehingga dapat disimpulkan bahwa jika diukur dengan indikator TVA, event pelantikan Presiden tersebut tidak memiliki kandungan informasi yang menyebabkan pasar bereaksi secara signifikan.

\section{SARAN}

Diharapkan para investor (pelaku pasar) mampu menyerap dan menyeleksi informasiinformasi relevan yang masuk ke pasar modal sehingga mampu mendapatkan hasil ekspektasi yang diharapkan. Selain itu, peneliti berharap investor tidak terburu-buru untuk melakukan aksi jual dan lebih bersikap rasional dalam pengambilan keputusan. Hal ini sebagai langkah antisipasi dan pencegahan ulah investor lain yang berusaha profit taking atau aksi ambil untung dengan membuat gejolak dengan informasi yang mereka buat sendiri. Oleh karena itu, investor juga harus pandai dan cermat memilih sumber informasi dalam pengambilan keputusan. 
Untuk penelitian selanjutnya disarankan, dalam meneliti kandungan informasi suatu peristiwa menggunakan paramater tambahan selain abnormal return dan trading volume activity. Parameter lain yang bisa digunakan yaitu bid-ask spread, periode menahan (holding period) ataupun menggunakan kajian-kajian tentang perilaku investor pasar modal. Penelitian ini juga menggunakan periode pengamatan yang singkat, yakni 11 hari. Ada beberapa model penelitian, misalnya market model dan meanadjusted model yang menggunakan periode estimasi, sehingga bisa memeperoleh periode ekspektasi yang lebih panjang daripada model market-adjusted ini.

\section{DAFTAR PUSTAKA}

Agustina, Dahniar Rahmita, 2013, Analisis Kandungan Informasi Isu Redenominasi Rupiah (Studi pada Perusahaan yang Termasuk Saham LQ45), Skripsi, Jurusan Manajemen Universitas Kanjuruhan.

Aseptin , Ria, 2011, Reaksi Pasar Modal Indonesia Terhadap Peristiwa Politik Dalam Negeri (Event Study Pada Peristiwa Mundurnya Sri Mulyani Indrawati Sebagai Menteri Keuangan), Skripsi, Fakultas Ekonomi Universitas Pembangunan Nasional "Veteran" Jawa Timur.

Fataruddin, 2011, Analisis Kandungan Informasi Kebijakan Kenaikan Tariff Dasar Listrik Terhadap Saham Perusahaan Manufaktur Yang Tercatat Aktif Di Bursa Efek Indonesia, Skripsi, Jurusan Manajemen Universitas Kanjuruhan.

Indrawati, Sri Rambat, 2010, Pengaruh Pergantian Presiden Republic Indonesia Terhadap Abnormal Return Saham Di Bursa Efek Indonesia, Skripsi, Jurusan Manajemen Universitas Kanjuruhan.

Islami, Lia Nur, 2011, Reaksi Pasar Modal Indonesia Terhadap Peristiwa Kemunduran Sri Mulyani Dari Jabatan Menteri Keuangan (Studi Saham Yang Terdaftar Di Bursa Efek Indonesia), Skripsi, Jurusan Manajemen Universitas Kanjuruhan.
Jogiyanto, H.M, 2003, Teori Portofolio Dan Analisis Investasi, Edisi 5, Cetakan Pertama, BPFE, Yogyakarta.

Maria Qifthiyah Alkaff. 2010. Pengaruh Pemilihan Presiden RI Tahun 2009 Terhadap Harga Saham Dan Volume Perdagangan Saham Perusahaan Di Bursa Efek Indonesia (Event Study Pada Saham Anggota JII). Skripsi, Jurusan Akuntansi Fakultas Ekonomi Universitas Pembangunan Nasional "Veteran" Jawa Timur.

Pronayuda, Teddy, 2006, Analisis Reaksi Pasar Terhadap Peristiwa Pengumuman Kabinet Indonesia Bersatu, Skripsi, Fakultas Ekonomi Universitas Islam Indonesia.

Sunariyah, 2000, Pengantar Pengetahuan Pasar Modal, Edisi Ketiga, UPP AMP YKPN, Yogyakarta.

Suryawijaya Dan Setiawan, 1998, Reaksi Pasar Modal Indonesia Terhadap Peristiwa Politik Dalam Negeri (Event Study Pada Peristiwa 27 Juli 1998), Jurnal Kelola Manajemen.

Swastika, Laksmi, Reaksi Pasar Modal Indonesia Terhadap Peristiwa Pemilihan Gubernur DKI Jakarta Putaran II 2012 (Event Study Pada Saham Anggota Indeks Kompas100), Jurnal, FEB Universitas Brawijaya.

Zaqi, Muhammad, 2006, Reaksi Pasar Modal Indonesia Terhadap Peristiwa-Peristiwa Ekonomi Dan Peristiwa-Peristiwa SosialPolitik Dalam Negeri (Studi Pada Saham LQ45 Di BEJ Periode 1999-2003), Tesis, Magister Manajemen Universitas Diponegoro. 